\title{
UPAYA INDONESIA DALAM MENJADIKAN BAHASA INDONESIA SEBAGAI BAHASA INTERNASIONAL DI ASIA TENGGARA
}

\author{
Ade Aprilyansyah \\ Program Studi Ilmu Hubungan Internasional, Fakultas Ilmu Sosial dan Ilmu Politik, Universitas \\ Komputer Indonesia, Jl. Dipatiukur No. 116, Bandung, 40212, Indonesia \\ E-mail : adeaprilyansyah@ymail.com
}

\begin{abstract}
Indonesian (Bahasa) experiences development in its function and position since it is set as the national language in which Indonesia improves the function of Indonesian (Bahasa) as an international language since 2009 by Act No. 24 year of 2009 where in Indonesian (Bahasa) showed has great opportunities and prospects to become an international language in Southeast Asia, which is supported by the number of domestic and foreign speakers of Indonesian and some other aspects. Yet, to make Indonesian as an international language, Indonesian experiences obstacles coming from the country and abroad.

In this study, the researcher tried to analyze what the measures of Indonesia are, what the constraints faced by Indonesia in making Indonesian (Bahasa) as an international language in Southeast Asia are, and how Indonesian (Bahasa) to be international language in Southeast Asia are. The method in this research was qualitative method. Most of the data were collected from interviews and literature and supported by the literature and website searches. The study was conducted in the Development and Language Improvement Department, the Ministry of Education and Culture of Indonesia and Indonesian Institute of Sciences The result showed that Indonesian (Bahasa) has great opportunities and prospects to become an international language in Southeast Asia, which is supported by the number of domestic and foreign speakers of Indonesian and some other aspects. Yet, to make Indonesian as an international language, Indonesian experiences obstacles coming from the country and abroad.
\end{abstract}

Keywords: Indonesian, Indonesia, International Languages.

\begin{abstract}
Abstrak
Bahasa indonesia mengalami perkembangan dalam fungsi dan kedudukannya sejak ditetapkan menjadi bahasa nasional dimana Indonesia meningkatkan fungsi bahasa indonesia menjadi bahasa internasional sejak tahun 2009 berdasarkan Undang-Undang Nomor 24 Tahun 2009 dimana bahasa indonesia menunjukkan peluang dan prospek besar untuk menjadi bahasa internasional di kawasan Asia Tenggara yang didukung dengan jumlah penutur bahasa indonesia di dalam maupun luar negeri dan aspek lain tetapi untuk menjadikan bahasa indonesia sebagai bahasa internasional, Indonesia mengalami hambatan yang datang dalam negeri maupun luar negeri.

Dalam penelitian ini peneliti mencoba untuk menganalisis apa saja langkah-langkah Indonesia, apa saja kendala yang dihadapi Indonesia dalam menjadikan bahasa Indonesia sebgai bahasa internasional di kawasan Asia Tenggara dan bagaimana bahasa Indonesia menjadi bahasa internasional di kawasan Asia Tenggara. Metode dalam penelitian menggunakan metode kualitatif. Sebagian besar data dikumpulkan dari hasil wawancara dan literatur serta didukung oleh studi pustaka dan penelusuran website. Penelitian dilakukan di Badan Pengembangan dan Pembinaan Bahasa dan Kementerian Pendidikan, Kebudayaan Indonesia PDII-LIPI. Hasil penelitian menunjukkan bahasa indonesia mempunyai peluang dan prospek besar untuk menjadi bahasa internasional di kawasan Asia Tenggara yang didukung dengan jumlah penutur bahasa indonesia di dalam maupun luar negeri dan aspek lain tetapi untuk menjadikan bahasa indonesia sebagai bahasa internasional, Indonesia mengalami hambatan yang datang dalam negeri maupun luar negeri.
\end{abstract}

Kata Kunci: Bahasa Indonesia, Indonesia, Bahasa Internasional 


\section{PENDAHULUAN}

\subsection{Latar Belakang Penelitian}

Sebagai langkah awal untuk menjadikan bahasa Indonesia sebagai bahasa Internasional di kawasan Asia Tenggara, Indonesia dalam Forum "Roundtable Conference Indonesia-Malaysia" yang diprakasai oleh Foreign Policy Study Group (FPSG)-Malaysia bersama dengan Eminent Person Group (EPG)Indonesia, the Indonesian Council on World Affairs (ICWA) dan Institut Kajian Internasional/FISIP UIN merekomendasikan penggunaan Bahasa Indonesia sebagai bahasa resmi di lingkungan ASEAN yang diselenggrakan di Kuala Lumpur pada tahun 2011 (http://www.antaranews.com/berita/29 179/bahasa-malaysiaindonesia-diusulkan-seba gai-bahasa-resmi-asean)

Indonesia melalui Kementrian Pendidikan dan Kebudayaan mengembangkan pusat pengajaran bahasa Indonesia di luar negeri yang tersebar di beberapa negara termasuk di kawasan Asia Tengggara dan akan memfasilitasi negara-negara yang berminat menyelenggarakan Bahasa Indonesia Untuk Penutur Asing (BIPA) dengan menyuplai buku-buku buku-buku tata bahasa Indonesia modern serta pengajar yang professional (http://kabarinews.com/pemerintah-inginbahasaindonesia-bisa-jadi-bahasainternasional/59594, diakses tanggal 05-032014)

Selain itu Kementerian Pendidikan dan Kebudayaan akan memfasilitasi warga asing maupun negara warga negara Indonesia di luar negeri terutama negara-negara di kawasan Asia Tenggara yang akan menyelenggarakan program Bahasa Indonesia Untuk Penutur Asing (BIPA) dengan menyuplai buku-buku dan mengirim pengajar profesional serta memberikan bantuan sarana yang dibutuhkan sebagai sarana untuk memperkenalkan bahasa Indonesia kepada negara lain.

Universitas Hong Bang, Universitas Nasional HCMC dan Universitas Sosial dan Humaniora telah membuka studi Bahasa Indonesia dan mengadakan lomba pidato dalam Bahasa Indonesia, lomba esai tentang Indonesia dan pameran kebudayaan yang diseleggarakan di Vietnam pada tanggal 12 Juni 2011 sebagai salah satu cara Indonesia melakukan diplomasi dengan negara lain serta mempromosikan bahasa Indonesia untuk menjadi bahasa internasional dikawasan Asia Tenggara (http://tekno.kom pas.com/read/2009/06/12/23524123/bahasa.in donesia.jadi.bahasa.kedua.di.ho.chi.minh.city, diakses tanggal 05-03-2015).

Bahasa Indonesia di Filipina mengalami perkembangan saat ini dimana warga negara Filipina banyak yang tertarik untuk belajar dan berlatih menggunakan bahasa Indonesia maka Kedutaan Republik yang berada di Filipina membuka pendidikan dan latihan bahasa Indonesia bagi pelajar dan mahasiswa indonesia, mahasiswa Filipina, dan masyarakat Filipina dengan bekerja sama dengan University of Philippines, University of Santo Thomas, Far Eastern University dan Saint Dominic College yang diselenggarakan di kedutaan dan universitas sebagai sarana untuk memperkenalkan bahasa Indonesia ke pada masyarakat Filipina (http://www.kemlu .go.id/manila/Pages/Divisions.aspx ?IDP=7, diakses tanggal 05-05-05-2015).

Selain di Thailand dan Filipina bahasa Indonesia diminati oleh warga negara Myanmar, Kamboja dan Laos. Untuk memfasilitasi warga negara yang berada Laos Kedutaan Besar Republik Indonesia di Laos membuka kursus bahasa Indonesia sebagai sarana untuk memperkenalkan dan mempromosikan bahasa Indonesia agar dapat digunakan di kawasan Asia tenggara sebagai langkah awal untuk menjadikan bahasa Indonesia sebagai bahasa Internasional (http://kemlu.go.id/Pages/Embassies.aspx ?ID $\mathrm{P}=9801 \& \mathrm{l}=\mathrm{id}$, diakses tanggal 29-04-2015).

Dari sudut pandang linguistik, bahasa Indonesia adalah salah satu dari banyak ragam bahasa Melayu. Seringkali bahasa Indonesia hanya dipandang sebagai alat komunikasi, namun perlu sadari potensi yang strategis bahasa Indonesia untuk melakukan ekspansi ke ranah yang lebih luas dengan melakukan 
diplomasi kebahasaan, salah satunya penggunaan bahasa Indonesia di kawasan Asia Tenggara sebagai langkah awal untuk menjadikan bahasa Indonesia sebagai bahasa Internasional (http://www.unsd.org/2 011/07/bahasa-indonesia.html,diakses tanggal 04-03-2014).

Rivalitas antara Indonesia dan Malaysia yang sama-sama mengusulkan bahasa Melayu dan Indonesia sebagai bahasa yang dapat digunakan di kawasan Asia Tenggara dalam memperebutkan pengaruh terhadap bahasa ASEAN dan juga datang dari negara yang bukan penutur bahasa Melayu maupun bahasa Indonesia seperti Filipina, Kamboja, Thailand, Laos, dan Myanmar (http:// nasional.news.viva.co.id/news/read/249562-in donesia-ataumelayu-bahasa-resmi-asean-, diakses tanggal 05-03-2015).

Maka berdasarkan latar belakang yang telah dipaparkan di atas, peneliti pun berkeinginan untuk mengadakan penelitian lebih lanjut dan mendalam yang akan tertuang dalam laporan penelitian berjudul

"Upaya Indonesia Dalam Menjadikan Bahasa Indonesia Sebagai Bahasa Internasional di Kawasan Asia Tenggara Tahun 2011-2014

\subsection{Rumusan Masalah}

Pokok masalah dalam penelitian ini adalah membentuk sebuah pertanyaan umum yaitu,

\subsubsection{Rumusan Masalah Mayor}

Bagaimana Upaya yang Dilakukan Indonesia Untuk Menjadikan Bahasa

Indonesia Sebagai Bahasa Internasional di Kawasan Asia Tenggara?

\subsubsection{Rumusan Masalah Minor}

1. Apa saja langkah-langkah yang telah dilakukan Indonesia dalam menjadikan bahasa Indonesia sebagai bahasa Internasional di kawasan Asia Tenggara?
2. Apa saja kendala yang dihadapi Indonesia dalam menjadikan bahasa Indonesia sebagai bahasa Internasional di kawasan Asia Tenggara?

3. Bagaimana prospek Indonesia dalam menjadikan bahasa Indonesia sebagai bahasa Internasional di kawasan Asia Tenggara?

\subsection{Maksud dan Tujuan Penelitian \\ 1.3.1 Maksud Penelitian}

Maksud dari penelitian ini adalah upaya apa saja yang dilakukan oleh Indonesia untuk menjadikan bahasa Indonesia sebagai bahasa internasional di kawasan Asia Tenggara

\subsubsection{Tujuan penelitian}

Tujuan dari penelitian ini adalah:

1. Untuk mengetahui, memahami, dan menganalisa langkah yang telah dilakukan Indonesia untuk menjadikan bahasa Indonesia sebagai bahasa Internasional di kawasan Asia Tenggara.

2. Untuk mengetahui, memahami, dan menganalisa kendala yang dihadapi Indonesia dalam menjadikan bahasa Indonesia sebagai bahasa Internasional di kawasan Asia Tenggara.

3. Untuk mengetahui, memahami, dan menganalisa prospek yang diperoleh Indonesia dalam menjadikan bahasa Indonesia sebagai bahasa Internasional di kawasan Asia Tenggara.

\subsection{Kegunaan Penelitian}

Manfaat hasil dari penelitian ini di harapkan berguna untuk berbagai pihak, baik secara teoritis maupun secara praktis, diantaranya sebagai berikut:

1. Secara teoritis diharapkan dapat dijadikan sebagai pedoman dalam upaya Indonesia dalam menjadikan bahasa indonesia sebagai bahasa internasional 
2. Secara praktis penelitian ini dapat :

a. Bagi peneliti dapat menambah wawasan dan ilmu pengetahuan peneliti di bidang Ilmu Hubungan Intenasional.

b. Bagi masyarakat sebagai informasi untuk mengetahui perkembangan dan pengetahuan kekuatan diplomasi Indonesia

\section{TINJAUAN PUSTAKA DAN KERANGKA PEMIKIRAN}

\subsection{Tinjauan Pustaka}

\subsubsection{Hubungan Internasional}

Hubungan Internasional yang pada dasarnya merupakan studi mengenai interaksi lintas batas Negara oleh state actor maupun non-state actor memiliki berbagai macam pengertian. Dalam buku "Pengantar Ilmu Hubungan Internasional" Anak Agung Banyu Perwita \& Yanyan Mochamad Yani. menyatakan bahwa:

"Studi tentang Hubungan Internasional banyak diartikan sebagai suatu studi tentang interaksi antar aktor yang melewati batas-batas Negara. Terjadinya Hubungan Internasional merupakan suatu keharusan sebagai akibat adanya saling ketergantungan dan bertambah kompleksnya kehidupan manusia dalam masyarakat internasional sehingga interdependensi tidak memungkinkan adanya suatu Negara yang menutup diri terhadap dunia luar"(Perwita \& Yani, 2005:3-4).

Kepentingan nasional sangat penting untuk menjelaskan dan memahami perilaku internasional. Konsep kepentingan nasional merupakan dasar untuk menjelaskan perilaku politik luar negeri suatu negara. Menurut May Rudi, Kepentingan nasional (national interest) merupakan tujuan-tujuan yang ingin dicapai sehubungan dengan hal yang dicitacitakan, dalam hal ini kepentingan nasional yang relatif tetap sama diantara semua negara atau bangsa adalah keamanan (mencakup kelangsungan hidup rakyatnya dan kebutuhanwilayahnya) serta kesejahteraan (prosperity), serta merupakan dasar dalam merumuskan atau menetapkan kepentingan nasional bagi setiap negara (Rudy. 2002 : 116).

\subsubsection{Diplomasi}

\subsubsection{Konsep Diplomasi}

Diplomasi merupakan manajemen hubungan antar negara atau hubungan antar negara dengan aktor-aktor hubungan internasional lainnya. Negara, melalui perwakilan resmi dan aktor-aktor lain berusaha untuk menyampaikan, mengkoordinasikan dan mengamankan kepentingan nasional khusus atau yang lebih luas, yang dilakukan melalui korespodensi, pembicaraan tidak resmi, saling menyampaikan cara pandang, lobby, kunjungan dan aktivitas-aktivitas lainnya yang terkait.

\subsubsection{Diplomasi Multijalur} (Multitrack Diplomacy)

Diplomasi multi jalur kerap melibatkan sejumlah unsur aktor dalam masyarakat, yaitu pemerintah pada jalur utama, dan pada jalur kedua terdapat LSM (NGO), kalangan profesional, kelompok agama, kelompok bisnis, aktivis advokasi, aktivis penelitian, pelatihan, pendidikan, organisasi penyedia dana, media massa, dan warga negara biasa (Shoelhi, 2011:83).

Track one diplomacy adalah diplomasi yang dilakukan oleh aktor negara yakni pemerintah (government-to-government) dan merupakan elemen penting dalam diplomasi. Track one diplomacy dilakukan dengan mempertimbangkan aspek formal dalam proses pemerintahan (Diamond dan McDonald, 2003 : 26-27).

Track four diplomacy menggambarkan keikutsertaan masyarakat dalam diplomasi 
yang disebut citizen diplomacy. Peran seluruh lapisan masyarakat akan lebih mudah dan jangkauannya luas dalam menjalin relasi untuk mewujudkan perdamaian dan kerjasama baik itu melalui kegiatan pertukaran, organisasi sukarela dan organisasi non-Pemerintah lainnya, special-interest groups hingga para selebritis dinyatakan sebagai aktor baru dalam dunia perpolitikan global. (Diamond dan McDonald, 2003 : 6061).

Track eight adalah pendanaan atau perwujudan perdamaian melalui penyediaan aset. Hal ini berhubungan langsung dengan komunitas-komunitas funding yakni baik yayasan maupun filantropis individual yang mampu menyediakan dukungan finansial untuk berbagai kegiatan yang dilaksanakan oleh jalur-jalur lain (Diamond \& Mc.Donald, 2003: 108)

\subsubsection{Diplomasi Publik \\ (Softpower Diplomacy)}

Dalam hubungan internasional dikenal

2 (dua) istilah yang popular, yakni hard power dan soft power. Perbedaan antara keduanya cukup mencolok ketika dilihat dari tiga hal: ciri, instrumen, dan implikasinya. Soft power berciri mengkooptasi atau mempengaruhi dan dilakukan secara tidak langsung. Sedangkan hard power bersifat memaksa atau memerintah dan dilakukan secara langsung. Instrumen yang digunakan oleh hard power antara lain kekuatan militer (military forces), sanksi, uang, suap (gratifikasi), ataupun bayaran. Adapun instrumen soft power yaitu berupa nilai, institusi, kebudayaan, dan kebijakan.

\subsubsection{Diplomasi Kebudayaan}

Diplomasi kebudayaan menurut

Wahyuni Kartika menjelaskan:

"Diplomasi kebudayaan adalah diplomasi yang memanfaatkan aspek kebudayaan untuk memperjuangkan kepentingan nasional dalam pencaturan masyarakat internasional. Diplomasi kebudayaan juga dianggap sebagai alat untuk memperlihatkan tingkat peradaban suatu bangsa (Warsito dan Kartikasari, 2007:25).

\subsubsection{Konsep Bahasa}

\subsubsection{Definisi dan Fungsi Bahasa}

Bahasa adalah alat komunikasi yang digunakan oleh manusia untuk berinteraksi dengan orang lain. Setiap orang pasti akan mendefinisikan "bahasa" dengan cara yang berbeda-beda berdasarkan dengan pendekatan teori yang mereka anut. Menurut teori struktural, bahasa dapat didefinisikan sebagai suatu sistem tanda arbitrer yang konvensional yang berkaitan dengan ciri sistem yang bersifat sistematik dan sistemik. Bersifat sistemik karena mengikuti ketentuanketentuan atau kaidah-kaidah yang teratur dan bersifat sistematik karena bahasa itu sendiri merupakan suatu sistem atau subsistemsubsistem (Soeparno, 2002: 1).

Dalam komunitas sosial, salah satu cara yang paling dasar dalam menentukan identitas dan mempengaruhi orang lain memandang diri kita adalah melalui bahasa. Adapun sarana linguistik yang dominan digunakan adalah dengan pemberian „nama. „Nama" akan membuat sesuatu menjadi berbeda dari yang lain, karena nama memiliki arti yang penting bagi penyandangnya. Orang tidak bisa membentuk sendiri identitas sosial yang diinginkannya, karena identitas itu terkait dengan cara orang lain memandang dirinya. Karena pentingnya bahasa sebagai sarana pembentukan identitas, maka bahasa memiliki pengaruh yang besar terhadap kendali sosial. Hubungan antara bahasa dan identitas merupakan hubungan yang kompleks, karena dipengaruhi oleh faktor individu, sosial, dan politik, yang secara bersama-sama membentuk identitas (Thomas \& Wareing 2007:223).

Dalam hubungan internasional setiap negara mempunyai bahasa yang dijadikan sebagai bahasa nasional setiap negara tetapi ada beberapa bahasa dijadikan sebagai bahasa 
Internasional yang digunakan dan dipelajari hampir diseluruh dunia. Bahasa memiliki peran penting dalam kehidupan berbangsa dan bernegara termasuk dalam interaksi antar Negara di dunia internasional salah satunya bahasa merupakan sebagai alat komunikasi antar Negara yang memiliki latar belakang dan identitas satu sama lain sehingga akan menimbulkan saling pengertian antar negara. Bahasa nasional dari suatu negara yang dijadikan sebagai bahasa internasional dapat menarik negara lain untuk mempelajari budaya yang dimiliki oleh negara bersangkutan dan dapat dijadikan sebagai sarana untuk memperkenalkan dan mempromosikan suatu negara dikancah internasional sehingga negara bersangkutan lebih dikenal. Bahasa menunjukan identitas suatu bangsa dan jati diri suatu bangsa di dunia internasional yang dapat dijadikan sebagai sarana untuk memperlihatkan keunggulan dalam bidang kebudayaan dibandingkan negara lain dan menunjukan eksistensinya di dunia internasional sehingga suatu bangsa dapat diakui oleh bangsa lain (Thomas \& Wareing 2007:223).

Secara kultural dengan adanya bahasa nasional yang dijadikan bahasa internasional dapat mengangkat peradaban suatu bangsa dalam bentuk kearifan lokal yang menjadi daya tarik suatu negara di dunia internasional dan dapat dijadikan sebagai sarana diplomasi suatu negara untuk memenuhi kepentingan nasionalnya dalam bidang kebudayaan. Bahasa memiliki peran untuk mengangkat harkat martabat bangsa di dunia internasional sebagai negara yang lebih maju dibandingkan negara lain sehingga suatu negara akan lebih diakui keberadaanya dan dapat meningkatkan daya tawar suatu negara dan dapat memberikan pengaruh yang kuat terdapat negara lain dalam forum-forum internasional. Dengan adanya bahasa internasional setiap saling kominikasi antar budaya dengan melakukan kerjasama tanpa melihat kultur social masing-masing negara dalam bidang ekonomi, politik, dan social budaya untuk memperkenalkan keanekaragaman budaya nya masing-masing dan pada akhirnya kebudayaan yang miliki termasuk bahasa menyebar luas ke mancanegara (Liliweri, 2001: 160).

Bahasa internasional merupakan bahasa yang banyak digunakan oleh setiap negara dan memiliki jumlah penutur terbanyak sebagai salah satu bahasa yang dapat digunakan dalam pergaulan internasional baik formal maupun informal setelah bahasa nasional yang dimiliki oleh masing-masing negara. Bahasa Internasional dianggap prestigious atau bahasa yang memiliki status yang tinggi seperti bahasa PBB, seperti bahasa Inggris, Perancis, Spanyol, dan China akibatnya bahasa tersebut memiliki peminat yang banyak untuk dipelajari dan dikuasai sebagai bahasa yang memiliki status prestigious yang memiliki peran penting dalam komunikasi internasional dalam pergaulan internasional (Artini dan Nitiasih, 2014: 4-7).

\subsection{Kerangka Pemikiran}

Perwita dan Yani yang mengemukakan bahwa Hubungan Internasional merupakan bentuk interaksi antara aktor atau anggota masyarakat yang satu dengan aktor atau anggota masyarakat lain yang melintasi batas-batas negara. Kerjasama Internasional yang awalnya dilakukan hanya pada permasalahan politik suatu negara tetapi saat ini berkembang isuisu baru isu ekonomi, lingkungan hidup, sosial dan kebudayaan. Dalam penelitian yang akan dilakukan Indonesia melakukan interaksi melalui kerjasama internasional dengan negara-negara yang berada dikawasan Asia Tenggara.

Indonesia melakukan interaksi melalui kerjasama internasional dengan negara-negara yang berada dikawasan Asia Tenggara dilatarbelakangi atas kepentingan Indonesia sesuai dengan konsep yang dikemukakan oleh T. May. Rudy bahwa Kepentingan nasional 
(national interest) merupakan tujuan-tujuan yang ingin dicapai sehubungan dengan hal yang dicita-citakan untuk itu Indonesia memperkenal budaya Indonesia terutama bahasa Indonesia kepada negara lain sehingga kepentingan nasional Indonesia dalam menjadikan bahasa Indonesia sebagia bahasa internasional di kawasan Asia Tenggara dapat tercapai.

Sesuai dengan kepentingan Indonesia yang menginginkan bahasa Indonesia menjadi bahasa Internasional, Indonesia melakukan diplomasi kebudayaan karena bahasa merupakan salah satu aspek dalam kebudayaan. Diplomasi Kebudayaan memberikan pengertian bahwa diplomasi dengan menggunakan kegiatan-kegiatan budaya seperti pengiriman misi kesenian ke negara-negara anggota ASEAN untuk menimbulkan dan memperoleh kesan atau citra baik. Melalui diplomasi kebudayaan, Indonesia memperjuangkan kepentingan nasionalnya dalam percaturan masyarakat Internasional terutama di kawasan Asia Tenggara dalam hal ini menjadikan bahasa Indonesia sebagai bahasa internasional.

Bahasa dijadikan sebagai salah satu alat komunikasi yang digunakan oleh Indonesia dalam melakukan diplomasi dengan negara lain dengan tujuan untuk menyampaikan pesan-pesan yang berkaitan dengan kepentingan nasional Indonesia melalui pertemuan-pertemuan internasional dan media massa dengan tujuan untuk menyampaikan keinginan Indonesia kepada negara lain sehingga dapat kepentingan nasional Indonesia dapat terpenuhi melalui jalur jalur diplomatik yang dilakukan perwakilan negara dan maupun jalur nonpemerintah yang dilakukan masyarakat.

Indonesia melakukan berbagai upaya dengan melakukan interaksi dengan negara

lain melalui komunikasi sehingga negara lain yang berada dikawasan Asia Tenggara dapat menerima penggunaan bahasa Indonesia di kawasan Asia Tenggara. Untuk menjadikan bahasa sebagai bahasa internasional Indonesia melakukan diplomasi kebudayaan melalui kegiatan-kegiatan budaya termasuk bahasa yang dilakukan di negara lain untuk memperkenalkan dan mempromosikan bahasa Indonesia sebagai bahasa internasional sehingga bahasa Indonesia dapat digunakan oleh negara-negara di kawasan Asia Tenggara.

\section{METODE PENELITIAN}

\subsection{Desain Penelitian}

Untuk melakukan sebuah penelitian, diperlukan sebuah desain atau rancangan yang berisi rumusan tentang objek yang akan diteliti. Metode penelitian yang digunakan peneliti dalam penelitian ini adalah metode penelitian kualitatif. Metode ini dipilih karena penelitian kualitatif bisa dilakukan oleh peneliti di bidang ilmu sosial dan politik, penelitian dalam metode ini tidak menggunakan analisis berupa grafik, bilangan dan numeral berdasarkan prosedur statistik. Penelitian dalam metode ini menyoroti masalah terkait upaya dari suatu negara di kancah internasional. Merujuk pada permasalahan yang diangkat serta variabel yang tersedia, maka peneliti hanya melakukan analisa data berdasarkan data-data serta informasi yang dikeluarkan oleh Badan Pengembangan dan Pembinaan Bahasa, Kementerian Pendidikan dan Kebudayaan, PDII-LIPI dan diimplementasikan dengan teori-teori dalam kajian Hubungan Internasional.

\subsection{Teknik Penentuan Informan}


Teknik Penentuan informan yang dipakai peneliti adalah dengan menggunakan teknik penentuan Purposive. Yaitu peneliti menentukan pihak-pihak informan berdasarkan tujuan, masalah dan variabel penelitian. Teknik yang digunakan adalah teknik wawancara sesuai dengan masalah yang akan diteliti.

\subsection{Teknik Pengumpulan Data}

Penelitian ini menggunakan teknik pengumpulan data melalui studi kepustakaan, penelusuran data online, dokumentasi, dan wawancara. Hal ini dikarenakan penelitian ini difokuskan pada diplomasi Indonesia dalam bidang kebahasaan dengan mengolah datadata yang diperoleh dari sumber yang relevan secara mendalam.

\subsubsection{Studi Pustaka}

Peneliti melakukan pengumpulan data melalui tulisan, artikel yang dikeluarkan oleh Badan Pengembangan dan Pembinaan Bahasa, Kementerian Pendidikan dan Kebudayaan dan PDII-LIPI serta menelaah teori, opini, membaca buku atau jurnal yang relevan dengan masalah yang diteliti. Peneliti juga menggunakan layanan internet dengan cara mengakses alamat situs berita online seperti detiknews, okezone, kompas dan situs berita lainnya serta situs resmi Badan Pengembangan dan Pembinaan Bahasa, Kementerian Pendidikan dan Kebudayaan dan Kementerian Luar Negeri dalam melakukan pengumpulan data terkait penelitian yang akan dilakukan.

\subsubsection{Penelusuran Data Online}

Dalam penelitian ini, peneliti menggunakan layanan internet dengan cara mengakses alamat situs Pengembangan dan Pembinaan Bahasa, Kementerian Pendidikan dan Kebudayaan serta situs lain yang terkait dengan segala informasi sesuai dengan penelitian yang akan dilakukan dan dapat dipertanggung jawabkan secara akademis.

\subsubsection{Metode Dokumentasi,}

Peneliti mengumpulkan data berupa catatan, transkrip, buku, surat kabar, majalah, dokumen, dan sebagainya. Dokumen bisa berbentuk tulisan atau gambar yang diperoleh melalui Badan Pengembangan dan Pembinaan Bahasa, Kementerian Pendidikan dan Kebudayaan, PDII-LIPI. dan sumber lain terkait dengan penelitian yang akan dilakukan.

\subsubsection{Wawancara}

Wawancara merupakan salah satu metode pengumpulan berita, data atau fakta untuk memperoleh keterangan. Pelaksanaannya dapat secara langsung, bertatap muka (face to face) dengan orang yang akan diwawancarai atau bisa secara tidak langsung dengan memanfaatkan akses teknologi melalui telepon, internet dan sebagainya. Dalam hal ini, peneliti mewawancarai narasumber terkait masalah yang akan diteliti. Salah satu narasumber yang terkait yaitu Pihak Badan Pengembangan dan Pembinaan Bahasa.

\subsection{Uji Keabsahan Data}

Dalam melakukan uji keabsahan data peneliti menggunakan metode triangulasi data dengan cara melakukan konfirmasi data yang diperoleh ke lembaga Badan Pengembangan dan Pembinaan Bahasa, Kementerian Pendidikan dan Kebudayaan dan PDII-LIPI dengan melakukan studi lapangan ke lembaga tersebut.

\subsection{Teknik Analisa Data}

Dalam penelitian kualitatif ini, peneliti menganalisis data dengan menggunakan 
teknik reduksi data. Artinya, data-data yang diperoleh, baik melalui studi pustaka, penelusuran online dan wawancara dihubungkan dengan teori atau konsep sebagai pijakan peniliti sesuai dengan keperluan penelitan berdasarkan dengan tujuan penelitian. Hal ini bertujuan supaya data yang digunakan berkorelasi dengan perumusan masalah yang telah dibuat. Penyajian Data, peneliti menyajikan data-data yang diperoleh dari hasil meneliti dan wawancara atau dari sumber-sumber internet sesuai dengan kebutuhan.

\section{Hasil Penelitian dan Pembahasan}

\subsection{Analisa Hasil Penelitian dan Pembahasan}

\subsubsection{Langkah-Langkah Indonesia Dalam} Menjadikan Bahasa Indonesia Sebagai Internasional di Kawasan Asia Tenggara

Dalam menjalankan diplomasi kebudayaan termasuk bahasa sebagai aspek kebudayaan, Indonesia tidak hanya melibatkan pemerintah sebagai satu-satunya jalur dalam memperjuangkan kepentingan nasional Indonesia di kawasan Asia tenggara tetapi melibatkan peran dari masyarakat, dan melalui penyediaan aset sehingga diplomasi yang dilakukan lebih efektif dan efisien dan dapat mempercepat Indonesia dalam mencapai kepentingan nasionalnya.

\subsubsection{Langkah-Langkah oleh Pemerintah \\ 4.1.1.1.1 Program Bahasa Indonesia Untuk Penutur Asing (BIPA) \\ Dalam perkembangan bahasa}

Indonesia di luar negeri indonesia melalui badan dan pembinaan bahasa indonesia mengembangkan bahasa indonesia untuk penutur asing (BIPA) di luar negeri yang mengalami perkembangan yang signifkan. Sebagai salah satu pemangku kepentingan program Bahasa Indonesia bagi Penutur Asing (BIPA), Badan Pengembangan dan Pembinaan Bahasa mendukung penguatan program BIPA melalui tugas dan fungsi yang dilaksanakan oleh unit-unit kerjanya berdasarkan Peraturan Menteri Pendidikan dan Kebudayaan Nomor 1 Tahun 2012 sebagaimana telah diubah dengan Peraturan Menteri Pendidikan dan Kebudayaan Nomor 69 Tahun 2012 tentang Organisasi dan Tata Kerja Kementerian Pendidikan dan Kebudayaan.

Dalam mengembangkan bahasa indonesia di luar negeri Indonesia melakukan terus melakukan pengembangan dengan mendirikan pusat pusat pembelajaran bahasa indonesia di dalam negeri maupun di luar negeri yang tersebar di beberapa negara dengan tujuan untuk memperkenalkan dan mempromosikan bahasa indonesia kepada warga negara asing terutama warga negara asing yang berada di Kawasan Asia Tenggara sehingga bahasa indonesia dapat menyebar luas ke manca negara.

\subsection{Program Darmasiswa Dalam Peningkatan Bahasa Indonesia}

Indonesia menyelenggarakan program darmasiswa, yaitu program beasiswa yang ditawarkan kepada semua mahasiswa asing dari negara-negara yang memiliki hubungan diplomatik dengan Indonesia untuk mempelajari Bahasa Indonesia, seni, musik dan kerajinan. Peserta dapat memilih salah satu universitas negeri dan swasta yang berbeda yang terletak di berbagai kota di Indonesia. Program ini yang diselenggarakan oleh Kementerian Pendidikan dan Kebudayaan bekerjasama dengan Kementerian Luar Negeri sebagai salah satu upaya indonesia untuk meningkatkan dan menumbuhkan minat Bahasa Indonesia dan budaya Indonesia di kalangan warga dari negara lain dan saling meningkatkan pengertian serta menunjukan kekuatan budaya yang miliki antara negaranegara yang berbeda.

Program darmasiwa digunakan sebagai sarana untuk melakukan diplomasi dengan cara membuka kesempatan bagi warga asing untuk mempelajari budaya dan bahasa indonesia di dalam negeri yang pada akhirnya warga negara asing telah mengikuti 
program darmasiswa dapat mengenalkan keunikan budaya indonesia termasuk bahasa indonesia kepada warga negara yang berasal dari negaranya sehingga bahasa indonesia lebih dikenal di manca negara dan dapat menjadi bahasa internasional di kawasan Asia Tenggara.

\subsection{Pameran Kesenian dan Kebudayaan di Luar Negeri}

Bentuk upaya lain yang dilakukan oleh pemerintah indonesia dengan menyelenggarakan pameran kesenian dan kebudayaan di luar negeri. Salah satunya dengan mengikuti festival seni dan budaya yang diselenggarakan antar negara Asia Tenggara dengan dikoordinasi oleh kementerian luar negeri bekerjasama dengan institusi-institusi terkait. Festival seni dan budaya antar negara asia tenggara memiliki esensi keragaman budaya yang sangat penting. Masing-masing delegasi boleh mempertunjukkan budayanya secara praktis, kreatif, dan inovatif.

\subsection{Penggunaan Bahasa Indonesia Dalam Pidato Kenegaraan}

Untuk mendukung upaya Indonesia dalam menjadikan indonesia internasional bahasa indonesia digunakan oleh kepala negara dalam pidato kenegaraan yang disampaikan forum-forum internasional salah satunya yang di selenggarakan oleh organisasi internasional termasuk ASEAN dan forumforum internasional yang diselenggarakan di Indonesia sebagai negara penerima yang merupakan bagian sarana dari wujud eksistensi bangsa dalam pergaulan internasional sesuai dengan perpres No.16 Tahun 2010.

Dalam pidato kenegaraan presiden dan wakil presiden didampingi oleh penerjemah untuk menyampaikan pidato dalam bahasa internasional sehingga negara lain mengerti pesan yang disampaikan oleh presiden dan wakil presiden dalam forum-forum internasional. Tujuan penggunaan pidato bahasa indonesia dalam forum internasionall untuk memperkenalkan bahasa indonesia kepada negara lain sehingga dapat meninjukan jati diri bangsa indonesia kepada negara lain yang berdampak pada semakin dikenalnya bahasa indonesia di manca negara dan pada akhirnya dapat menjadi bahasa internasional di kawasan Asia Tenggara.

\subsubsection{Langkah-Langkah oleh Masyarakat}

Pada tahun 2011 MASYINDO HCMC menyelenggarakan Indonesia Day 2011 dengan bekerja sama dengan KJRI Ho Chi Minh untuk lebih mendekatkan warga negara Indonesia dengan masyarakat Vietnam dan memperkenalkan kebudayaan Indonesia melalui pagelaran kesenian dan kebudayaan yang meliputi bahasa, kesenian maupun hasil karya seperti batik dan keris.

Selain Vietnam di beberapa negara terdapat komunitas warga negara indonesia sebagai bentuk diaspora indonesia dengan tujuan untuk menjaga menunjukan eksistensi warga indonesia yang berada di luar negeri dan sarana untuk saling memperkuat rasa kebersamaan warga negara indonesia di luar negeri. Komunitas warga negara indonesia menyelenggaran berbagai kegiatan dengan bekerja sama dengan KBRI untuk warga negara Indonesia tetapi kegiatan tersebut tanggapan cukup posistif dari warga negara indonesia maupun asing.

Kegiatan-kegiatan yang diselenggarakan tidak hanya diikuti oleh warga negara indonesia melainkan warga negara asing yang menikah dengan warga negara indonesia yang menetap di luar negeri dan keluarga serta teman-teman dari warga negara asing sehigga secara tidak langsung dapat memperkenalkan bahasa indonesia kepada negara lain yang akan membantu pemerintah dalam proses menjadikan bahasa Indonesia sebagai bahasa internasional di kawasan Asia Tenggara.

Terdapat perkumpulan pelajar indonesia yang tersebar di kawasan Asia Tenggara yang dinamakan dengan Perkumpulan Pelajar Indonesia PPI meliputi PPI Malaysia, Brunei Darussalam, Filipina, 
Singapura, Malaysia dan Perhimpunan Mahasiswa Thailand (PERMITHA) yang menyelenggarakan berbagai kegiatan bagi warga negara indonesia maupun warga negara asing sebagai peserta. Kegiatan-kegiatan yang dijalankan meliputi lomba pidato, simposium, kongres dan konferensi internasional bahasa indonesia sebagai bentuk diplomasi yang dilakukan oleh masyarakat dengan diwakili oleh pelajar yang berada di luar negeri. Pada tahun 2012 PPI Singapura menyelenggarakan Indonesian Arts Festival berupa festival seni di universitas dengan peserta dari beberapa universitas yang mempertunjukan teater, musik, dan seni indonesia sebagai sarana untuk mengenalkan bahasa indonesia sehingga bahasa indonesia lebih dikenal di mannca negara (http://ppidunia.org/, diakses pada tanggal 13-07-2015).

\subsubsection{Langkah-Langkah}

\section{Penyediaan Aset}

Indonesia melakukan penyediaan aset dengan memfasilitasi lembaga atau institusi yang berada di luar negeri berupa mengirim bahan ajar dan mengirim tenaga pengajar dan bahan ajar bahasa indonesia untuk membuka pembelajaran bahasa indonesia di Kedutaan Besar Republik Indonesia (KBRI) dan Konsulat Jederal Republik Indonesia (KJRI) yang berada di luar negeri secara berkala dan juga lembaga-lembaga pengajaran bahasa indonesia yang didirikan oleh warga negara Indonesia di luar negeri maupun warga negara asing. Pemerintah memfasilitasi lembaga atau institusi yang menyelenggarakan kegiatan kebahasaan di dalam maupun luar negeri sebagai salah satu bentuk upaya dari indonesia untuk mempercepat proses menjadikan bahasa Indonesia sebagai bahasa internasional di kawasan Asia Tenggara.

Kemajuan teknologi informasi dan komunikasi mengalami perkembangan sangat signifikan yang menjadi bagian dari kehidupan manusia dan kehidupan manusia yang kovensial menjadi modern. Untuk itu penyediaan aset yang dilakukan oleh pemerintah tidak hanya dengan menyuplai buku-buku dan tenaga pengajar tetapi memanfaatkan teknologi dan informasi dalam peningkatan fungsi bahasa indonesia dapat membuat bahasa indonesia akan lebih mudah untuk pamahi dan membuat warga negara asing semakin tertarik untuk belajar bahasa.

\subsubsection{Kendala-Kendala Dalam Menjadikan Bahasa Internasional di Kawasan Asia Tenggara \\ Dalam menjadikan bahasa indonesia} sebagai bahasa internasional terdapat hambatan yang berasal dari dalam negeri salah satunya sikap negatif masyarakat terhadap bahasa Indonesia. Bahasa Indonesia dalam negeri belum menjangkau kelompok yang belum dapat berbahasa Indonesia dengan baik dan benar akibat tidak meratanya pendidikan di Indonesia.

Dalam penggunaanya, masih banyak orang Indonesia yang tidak memperdulikan bahasa Indonesia yang baik dan benar dan lebih bangga menggunakan bahasa inggris dibandingkan dengan bahasa indonesia yang menjadi salah satu faktor penghambat bahasa Indonesia untuk dikenal oleh masyarakat di dunia. Pola pikir masyarakat dengan menjadikan bahasa asing khusunya bahasa Inggris sebagai status sosial membuat penggunaan bahasa daerah dan bahasa Indonesia telah dikalahkan oleh penggunaan bahasa Inggris di negeri sendiri. Masyarakat berpikir bahwa menggunakan bahasa asing dapat meningkatkan status sosial dan dianggap sebagai orang yang berpendidikan.

Hambatan lain datang dari anggaran yang jumlahnya tidak memadai sehingga mengakibatkan program-program untuk mengenalkan bahasa indonesia kepada negara lain menjadi terhambat.

\subsubsection{Prospek Indonesia Dalam Menjadikan Bahasa Internasional di Kawasan Asia Tenggara \\ Bahasa terus berkembang hingga ke} luar negeri dan menyebar luas ke manca negara melalui warga Indonesia bekerja, tinggal di luar negeri dan lembaga pengajaran 
bahasa Indonesia yang didirikan oleh pemerintah maupun warga negara Indonesia di luar negeri dan warga negara asing membuat bahasa indonesia semakin terkenal di mancanegara yang berdampak pada bertambahnya jumlah penutur bahasa indonesia di luar negeri. Bahasa Indonesia memiliki penutur asli yang tersebar di luar negeri sebanyak 240 juta menjadikan bahasa Indonesia sebagai bahasa terbesar kelima dan di Asia Tenggara bahasa Indonesia menduduki peringkat 1 dengan jumlah penutur terbanyak,

Bahasa Indonesia memiliki peluang besar untuk menjadi bahasa internasional dikawasan asia tenggrara dimana bahasa indonesia pada akhirnya dipelajari dan menjadi salah satu bahasa yang dugunakan oleh semua negara yang berada di kawasan Asia Tenggara. Peningkatan bahasa indonesia menjadi bahasa internasional akan memberikan dampak positif bagi indonesia terutama dalam pergaulan internasional yang dapat menunjukan kedaulatan bangsa Indonesia sebagai bangsa maju terutama dalam bidang kebudayaan yang akan membuat bahasa indonesia semakin terkenal di mancanegara dan membuat daya tawar dan posisi indonesia di manca negara akan meningkat sehingga indonesia menjadi salah satu negara yang memiliki nilai strategis dan dapat akan memberikan dampak positif bagi Indonesia dalam memenuhi kebutuhan nasionalnya di dunia internasional.

\section{KESIMPULAN DAN SARAN}

\subsection{Kesimpulan}

Untuk menjadikan bahasa indonesia sebagai bahasa internasional pemerintah melakukan langkah-langkah sebagai berikut :

1. Penyelenggaraan program bahasa indonesia untuk penutur asing (BIPA) dengan membuka pembelajaran bahasa indonesia di Kedutaan Besar Republik Indonesia (KBRI) dan Konsulat Jenderal Republik Indonesia (KJRI) di luar negeri.
2. Penyelenggaraan program darmasiswa, yaitu program beasiswa yang ditawarkan kepada semua mahasiswa asing dari negaranegara yang memiliki hubungan diplomatik dengan Indonesia untuk mempelajari Bahasa Indonesia, seni, musik dan kerajinan..

3. Penyelenggaraan pameran kesenian dan kebudayaan di luar negeri yang dilakukan oleh Kementerian Luar Negeri dan Kementerian Pendidikan dan Kebudayaan sebagai salah salah cara untuk menunjukan kekayaan nilai-nilai dari budaya indonesia.

4. Bahasa indonesia digunakan oleh kepala negara dalam pidato kenegaraan yang disampaikan forum-forum internasional salah satunya yang di selenggarakan oleh organisasi internasional termasuk ASEAN dan forum internasional.

Terdapat kendala internal maupun eksternal yang dihadapi Indonesia dalam menjadikan bahasa indonesia sebagai bahasa internasional di kawasan Asia Tenggara. Kendala internal datang dari sikap masyarakat negatif penggunaan bahasa indonesia dan rendahnya kualitas sumber daya manusia akibat tidak meratanya pendidikan di Indonesia menyebabkan sulitnya mengembangkan bahasa Indonesia.

Sedangkan hambatan eksternal yang dihadapi Indonesia, yaitu bahasa indonesia berasal dari bahasa melayu yang berkembang menjadi bahasa indonesia sehingga di manca negara bahasa melayu lebih sudah diakui sebagai bahasa universal yang digunakan oleh beberapa negara terutama negara-negara yang berada di kawasan Asia Tenggara.

\subsection{Saran}

1. Untuk Pemerintah, pemerintah perlu memberikan perhatian lebih dan melakasanakan program-program secara lebih efektif dan efisien terhadap upaya Indonesia dalam menjadikan bahasa indonesia sebagai bahasa internasional di kawasan Asia Tenggara yang selama ini kurang diperhatikan oleh pemerintah. 
2. Untuk Badan Pengembangan dan Pembinaan Bahasa, instansi terkait dapat meningkatkan kerjasama satu sama lain secara lebih intensif yang dikoordinasi oleh Pengembangan dan Pembinaan Bahasa karena dalam menjadikan bahasa indonesia sebagai bahasa internasional tidak hanya melibatkan satu instansi tetapi perlu ada dukungan dari instansi lain.

3. Untuk masyarakat luas, agar turut mendukung dengan cara menggunakan bahasa indonesia baik dan benar serta bangga menggunakan bahasa indonesia sebagai jati diri bangsa indonesia yang membedakan bangsa indonesia dengan bangsa.

\section{DAFTAR PUSTAKA}

\section{Acuan dari buku}

Artini, Putu, Luh dan Nitiasih, Kerti, Putu. 2014. Bilingualisme dan Pendidikan Bilingual. Yogyakarta. Graha Ilmu

Diamond, Louise dan McDonald, John. 2003. Multi-Track Diplomacy: A Systems Approach to Peace (4th ed.). West Hartford CT: Kumarian Press

Liliweri, Alo. 2004. "Dasar-dasar Komunikasi Antar Budaya". Yogyakarta: Pustaka Pelajar

Perwita, A.A Banyu, dan Yanyan Moch. Yani. 2005. Pengantar Ilmu Hubungan Internasional. Bandung: PT Remaja Rosdakarya.

Rudy, Teuku May. 2002. Studi Strategis: Dalam Transformasi Sistem Internasional Pasca Perang Dingin. Bandung: PT. Refika Aditama

Shoelhi, Mohammad. 2011. Diplomasi Praktik Komunikasi Internasional. Bandung. Simbiosa Rekatama Media.
Soeparno. 2002. Dasar-Dasar Linguistik Umum. Yogyakarta : Tiara Wacana

Thomas, Linda dan Shân Wareing. 2007. Bahasa, Masyarakat, dan Kekuasaan. Yogyakarta. Pustaka Pelajar.

Warsito, Tulus dan Wahyuni Kartikasari, 2007.Diplomasi Kehudayaaan Konsep dan Relevansi Bagi Negara Berkembang: Studi Kasus Indonesia. Yogyakarta: Ombak

\section{Acuan artikel dalam situs}

http://www. Antaranews . com / berita / 269179 / bahasa - malaysiaindonesia diusulkan-sebagai- bahasa - resmi - asean, diakses tanggal 05-03-2014

http://nasional . news. Viva . co . id news read / 249562 - indonesia - atau - melayu bahasa-resmi-asean-, diakses tanggal 0503-2014

http://www.unsd.org/2011/07/bahasaindonesia.html, diakses tanggal 05-032014

http://tekno.kompas.com/read/2009/06/12/ 23524123/bahasa.indonesia.jadi.bahasa.ke dua.di.ho.chi.minh.city, diakses tanggal 05-03-2014

http://kabarinews.com/pemerintah-inginbahasa-indonesia-bisa-jadi-bahasainternasional/59594, 05-03-2014 diakses tanggal http://pdaa.publicdiplomacy.org/?page_id= 6, diakses tanggal 31 Maret 2015

http://kemlu.go.id/Pages/Embassies.aspx?I $\mathrm{DP}=9801 \& \mathrm{l}=\mathrm{id}$, diakses tanggal 29-042015

http://www.kemlu.go.id/manila/Pages/Divi sions. aspx ? IDP=7, diakses tanggal 0505-05-2015 